\title{
PERTUMBUHAN TANAMAN KELAPA SAWIT (Elaeis guineensis Jacq.) DI PEMBIBITAN UTAMA DENGAN PEMBERIAN Trichoderma KOMPOS DAN PUPUK MAJEMUK LENGKAP
}

\author{
Chairunnisa Nur Wellys ${ }^{1}$ dan Yetti Elidar ${ }^{2}$ \\ ${ }^{1}$ Program Studi Agroekoteknologi, Fakultas Pertanian, Universitas Mulawarman, \\ Indonesia. \\ ${ }^{2}$ Program Studi Agroekoteknologi, Fakultas Pertanian, Universitas Mulawarman, \\ Indonesia. \\ E-Mail: chairunnisanw03@gmail.com; elidaryetti@gmail.com
}

\begin{abstract}
ABSTRAK
Pertumbuhan Tanaman Kelapa Sawit (Elaeis guineensis Jacq.) Di Pembibitan Utama Dengan Pemberian Trichoderma Kompos Dan Pupuk Majemuk Lengkap. Tujuan penelitian untuk mengetahui interaksi antara pemberian Trichoderma kompos dan konsentrasi Gandasil D, serta mengetahui perlakuan Trichoderma kompos dan konsentrasi Gandasil D yang memberikan pertumbuhan tanaman kelapa sawit terbaik di pembibitan utama. Penelitian dilaksanakan sejak bulan September 2018 sampai Januari 2019, di Perumahan Universitas Mulawarman, Batu Besaung, Sempaja.

Hasil penelitian diperoleh pada variabel pengamatan, yaitu: tinggi tanaman, lingkaran bonggol, jumlah pelepah daun, dan panjang pelepah daun. Interaksi antara Trichoderma kompos dan Konsentrasi Gandasil D menunjukan berbeda tidak nyata terhadap semua variabel pengamatan. Trichoderma kompos menunjukan berbeda sangat nyata terhadap jumlah pelepah daun umur 4 Minggu Setelah Perlakuan (MSP) dan berbeda yang nyata pada umur 12 MSP tetapi berbeda tidak nyata terhadap variabel pengamatan lain. Kompos $500 \mathrm{~g}$ $\operatorname{tanaman}^{-1}$ memberikan pertumbuhan terbaik bagi tanaman kelapa sawit. Konsentrasi Gandasil D menunjukan berbeda nyata terhadap jumlah pelepah daun pada umur 2 dan $6 \mathrm{MSP}$, berbeda sangat nyata pada umur 4 MSP, tetapi berbeda tidak nyata terhadap variabel pengamatan yang lain Konsentrasi $6 \mathrm{~g}$ Gandasil D L ${ }^{-1}$ air memberikan pertumbuhan terbaik bagi tanaman kelapa sawit.
\end{abstract}

Kata kunci : Trichoderma compost, Gandasil D, main nursey, oil palm.

\begin{abstract}
Growth of Oil Palm Plants (Elaeis guineensis Jacq.) In the Main Nursery by Giving Compost Trichoderma and Compound Fertilizers. The purpose of this study was to determine the interaction between the Trichoderma compost and the concentration of Gandasil D, included knowing the treatment of Trichoderma compost and the concentration of Gandasil D to provide the best growth of oil palm plants in main nursery. The research was carried out at Perumahan Universitas Mulawarman, Batu Besaung Sempaja from September 2018 to January 2019.

The research results obtained on the observation variables, namely: high plants, Stem circle, number of leaf midribs, and length of leaf midribs. Shows the interactions between the treatment of Trichoderma compost and the concentration of Gandasil D had no significantly different for all observation variables. Treatment of Trichoderma compost showed a higly significant difference in the number of midribs leaves aged 4 weeks after treatment (WAT) and significantly different at age 12 WAT but it had no significantly different on other observation variables. Treatment of $500 \mathrm{~g}$ compost plant $^{-1}$ provides the best growth for oil palm plants. The concentration of Gandasil D showed a significantly different on number of leaf midribs aged 2 and 6 WAT, and it had highly significant different at age 4 WAT but it had no significantly different from other observation variables. Treatment of concentration $6 \mathrm{~g}$ Gandasil $\mathrm{D} \mathrm{L}^{-1}$ water provides the best growth for plants oil palm.
\end{abstract}

Key words : Trichoderma compost, Gandasil D, main nursey, oil palm. 


\section{PENDAHULUAN}

Provinsi Kalimantan Timur merupakan salah satu sentral penanaman kelapa sawit di Indonesia. Luas perkebunan kelapa sawit di Kalimantan Timur pada tahun 2013 seluas 944.826 ha dengan luas areal tanaman menghasilkan (TM) 397.635 ha memiliki produksi $6.901 .602 \mathrm{Mg}$ dan produktivitas 17,357 $\mathrm{Mg} \mathrm{ha}{ }^{-1}$. Pada tahun 2014 luas lahan kelapa sawit 1.020.413 ha dengan luas areal tanaman menghasilkan (TM) 500.512 ha memiliki produksi 9.628 .072 $\mathrm{Mg}$ dan produktivitas 19,236 $\mathrm{Mg} \mathrm{ha}^{-1}$. Pada tahun 2015 luas lahan kelapa sawit 1.090.106 ha dengan luas areal tanaman menghasilkan (TM) 621.777 ha memiliki produksi $10.812 .893 \mathrm{Mg}$ dan mengalami penurunan produktivitas menjadi 17,390 $\mathrm{Mg}$ ha $^{-1}$. Pada tahun 2016 luas lahan kelapa sawit 1.150.078 ha dengan luas areal tanaman menghasilkan (TM) 763.896 ha memiliki produksi 11.418.110 $\mathrm{Mg}$ dan kembali mengalami penurunan produktivitas menjadi $14,947 \mathrm{Mg} \mathrm{ha}^{-1}$. Pada tahun 2017 luas lahan kelapa sawit 1.192.342 ha dengan luas areal tanaman menghasilkan (TM) 788.311 ha memiliki produksi $13.164 .310 \mathrm{Mg}$ dan mengalami kenaikan produktivitas dari tahun sebelumnya menjadi $16,699 \mathrm{Mg} \mathrm{ha}{ }^{-1}$. (Dinas Perkebunan Provinsi Kalimantan Timur, 2018).

Menurunnya produktivitas kelapa sawit disebabkan banyaknya kelapa sawit yang sudah berumur diatas 25 tahun sehingga tanaman kelapa sawit kurang produktif. Oleh karena itu perlu dilakukan replanting atau peremajaan terhadap tanaman kelapa sawit supaya dapat produktif kembali. Dalam kegiatan replanting diperlukan pembibitan (pre nursery dan main nursery). Tujuan dari pembibitan adalah untuk mempersiapkan bibit yang baik dengan kriteria kuat, sehat, dan kokoh. Titik kritis pemeliharaan kelapa sawit terletak pada pemupukan yang dimulai dari pembibitan awal sampai pembibitan utama, tanah memiliki keterbatasan unsur hara karena ditanam di dalam polybag (Sari et al., 2015). Pasokan hara di tahap pembibitan ini sangat penting karena merupakan periode kritis yang menentukan keberhasilan tanaman dalam mencapai pertumbuhan yang baik di pembibitan.

Penggunaan pupuk organik memberik-an pengaruh yang besar terhadap sifat fisik, kimia, dan biologi tanah. Salah satu jenis pupuk organik adalah pupuk kompos. Kompos memiliki sifat-sifat alami yang tidak merusak tanah, menyediakan unsur hara makro dan mikro, berfungsi untuk meningkatkan daya air, aktivitas mikrobiologi tanah dan nilai kapasitas tukar kation serta memperbaiki struktur tanah. Tanaman kelapa sawit sangat rentan terhadap serangan penyakit busuk pangkal batang yang disebabkan oleh jamur Ganoderma sp. Untuk mencegah terjadinya serangan tersebut, perlu diberikan jamur Trichoderma sp. sedini mungkin pada tanaman yang masih di pembibitan. Pemberian jamur Trichoderma sp. dapat menghambat pertumbuhan serta penyebaran racun jamur penyebab penyakit bagi tanaman seperti cendawan Ganoderma yang dapat menyebabkan penyakit busuk pangkal batang pada tanaman kelapa sawit dan jamur Rigidoporus lignosus yang dapat 
menyebabkan penyakit akar putih pada tanaman karet.

Disamping penggunaan pupuk organik, penambahan unsur hara juga dapat diberikan melalui pupuk anorganik, salah satunya yaitu dengan pupuk Gandasil D. Pupuk Gandasil D merupakan pupuk majemuk lengkap yang didalamnya mengandung unsur hara makro dan mikro, dengan pemberian pupuk ini akan memperkaya unsur hara dalam tanah sehingga mampu mempercepat pertumbuhan vegetatif tanaman.

\section{METODA PENELITIAN}

\subsection{Tempat dan Waktu}

Penelitian bertempat di Perumahan Universitas Mulawarman, Batu Besaung Sempaja. Pada bulan September 2018-Januari 2019.

\subsection{Bahan dan Alat}

Bahan yang digunakan dalam penelitian ini adalah bibit kelapa sawit berumur 5 bulan, pupuk NPK, pupuk kompos, dedak, starter Trichoderma sp., pupuk Gandasil D, tanah top soil, insektisida regent 50, agrimec, dan air.

Alat yang digunakan adalah cangkul, polibag berukuran $40 \mathrm{~cm} \times 50 \mathrm{~cm}$, meteran, penggaris, beaker glass, stik kayu, tali rafia, arit, pisau, gembor, paralon, kalkulator,alat tulis, dan alat dokumentasi.

\subsection{Rancangan Percobaan}

Percobaan disusun dalam Rancangan Acak Kelompok (RAK) dengan analisis faktorial 4 x 4 dengan tiga kali ulangan.

Faktor yang pertama adalah perlakuan Trichoderma kompos (K) yang terdiri dari empat taraf, yaitu :

$\mathrm{k}_{0}=$ Kontrol

$\mathrm{k}_{1}=100 \mathrm{~g}$ Trichoderma sp.tanaman ${ }^{-1}$

$\mathrm{k}_{2}=500 \mathrm{~g} \mathrm{kompos} \mathrm{tanaman}^{-1}$

$\mathrm{k}_{3}=100 \mathrm{~g}$ Trichoderma sp.dan $500 \mathrm{~g}$ kompos tanaman $^{-1}$

Faktor kedua adalah konsentrasi gandasil D (G) yang terdiri dari empat taraf, yaitu :

$\mathrm{g}_{0}=$ Kontrol

$\mathrm{g}_{1}=2 \mathrm{~g}$ Gandasil D L $^{-1}$ air

$\mathrm{g}_{2}=4 \mathrm{~g}$ Gandasil D L $^{-1}$ air

$\mathrm{g}_{3}=6 \mathrm{~g}$ Gandasil D L $^{-1}$ air

Data hasil penelitian dianalisis dengan sidik ragam. Apabila terdapat perbedaan yang nyata maka untuk membandingkan antara dua rata-rata perlakuan akan dilanjutkan dengan uji Beda Nyata Terkecil (BNT) pada taraf $5 \%$.

\section{HASIL PENELITIAN DAN PEMBAHASAN}

\subsection{Tinggi Tanaman}

Hasil sidik ragam menunjukan bahwa pemberian Trichoderma kompos (K) dan konsentrasi Gandasil D (G) serta interaksinya berbeda tidak nyata terhadap tinggi bibit kelapa sawit umur 2-16 MSP. Hasil pengamatan rata-rata tinggi tanaman dapat dilihat pada Tabel 1 .

Tabel 1. Rekapitulasi tinggi tanaman kelapa sawit (cm) umur 2-16 MSP dengan pemberian Trichoderma kompos dan pupuk Gandasil D

\begin{tabular}{lllllllll}
\hline \multicolumn{10}{c}{ Tinggi Tanaman $(\mathrm{cm})$} \\
\hline Perlakuan & 2 & 4 & 6 & 8 & 10 & 12 & 14 & 16 \\
\cline { 2 - 8 }
\end{tabular}




\begin{tabular}{ccccccccc} 
& \multicolumn{1}{c}{ MSP } & MSP & MSP & MSP & MSP & MSP & MSP & MSP \\
\cline { 2 - 9 } Trichoderma & & & & & & & & \\
Kompos (K) & tn & tn & tn & tn & tn & tn & tn & tn \\
k0 & 35,79 & 38,21 & 40,71 & 43,33 & 49,48 & 56,79 & 60,92 & 64,42 \\
k1 & 38,77 & 41,42 & 47,17 & 50,81 & 56,84 & 63,46 & 68,38 & 72,75 \\
k2 & 39,6 & 44,11 & 47,38 & 50,41 & 56,63 & 64,83 & 69,25 & 74,33 \\
k3 & 38,98 & 42,21 & 46,88 & 49,21 & 53,39 & 60,88 & 66,38 & 72,13 \\
\hline Gandasil D & & & & & & & & \\
(G) & tn & tn & tn & tn & tn & tn & tn & tn \\
g0 & 35,06 & 38,86 & 44,68 & 47,88 & 53,14 & 62,00 & 67,83 & 73,83 \\
g1 & 36,17 & 39,13 & 42,34 & 46,15 & 51,72 & 58,25 & 62,13 & 67,33 \\
g2 & 37,93 & 41,17 & 45,58 & 48,07 & 53,56 & 61,92 & 65,88 & 70,25 \\
g3 & 43,96 & 46,79 & 49,53 & 51,65 & 57,92 & 63,80 & 69,08 & 72,21 \\
\hline Interaksi & & & & & & & & \\
KxG) & tn & tn & tn & tn & tn & tn & tn & tn \\
k0g0 & 30,67 & 33,33 & 34,97 & 38,57 & 46,00 & 54,00 & 59,33 & 65,00 \\
k0g1 & 30,33 & 34,00 & 37,93 & 41,77 & 47,67 & 54,67 & 57,00 & 60,33 \\
k0g2 & 38,00 & 40,00 & 41,47 & 43,10 & 49,37 & 58,67 & 64,00 & 66,00 \\
k0g3 & 44,17 & 45,50 & 48,47 & 49,90 & 54,87 & 59,83 & 63,33 & 66,33 \\
k1g0 & 37,00 & 39,67 & 51,67 & 54,27 & 58,00 & 66,67 & 71,50 & 76,67 \\
k1g1 & 38,67 & 41,00 & 44,20 & 51,37 & 62,77 & 67,00 & 70,00 & 76,00 \\
k1g2 & 32,73 & 36,33 & 42,77 & 45,17 & 47,27 & 54,17 & 58,33 & 62,33 \\
k1g3 & 46,67 & 48,67 & 50,03 & 52,43 & 59,33 & 66,00 & 73,67 & 76,00 \\
k2g0 & 39,23 & 43,77 & 46,87 & 50,47 & 56,73 & 66,00 & 72,17 & 78,00 \\
k2g1 & 38,00 & 42,33 & 43,93 & 47,63 & 51,23 & 61,00 & 66,00 & 72,00 \\
k2g2 & 42,00 & 45,00 & 50,83 & 52,50 & 59,57 & 66,50 & 69,50 & 74,67 \\
k2g3 & 39,17 & 45,33 & 47,90 & 51,00 & 58,97 & 65,83 & 69,33 & 72,67 \\
k3g0 & 33,33 & 38,67 & 45,20 & 48,23 & 51,83 & 61,33 & 68,33 & 75,67 \\
k3g1 & 37,67 & 39,17 & 43,30 & 43,83 & 45,20 & 50,33 & 55,50 & 61,00 \\
k3g2 & 39,00 & 43,33 & 47,27 & 51,50 & 58,03 & 68,33 & 71,67 & 78,00 \\
k3g3 & 45,83 & 47,67 & 51,73 & 53,27 & 58,50 & 63,53 & 70,00 & 73,83 \\
\hline
\end{tabular}

Pemberian Trichoderma kompos pada media tanah tidak memberikan pengaruh, hal ini diduga karena Trichoderma yang diberikan dalam campuran starter Trichoderma dan dedak belum mengalami perkembangan. Unsur hara $\mathrm{N} 0,25 \%$ yang tersedia di dalam tanah tergolong sedang sehingga mampu membantu pertumbuhan tanaman. Hal ini sesuai dengan pendapat Harman et al. (2004), pemberian Trichoderma sp. pada medium tumbuh dapat meningkatkan efisiensi penggunaan nitrogen. Ditambahkan oleh pendapat Lingga dan Marsono (2008), nitrogen dalam jumlah yang optimum berperan dalam mempercepat pertumbuhan tanaman secara keseluruhan, khususnya batang dan daun. Pemberian konsentrasi Gandasil D berbeda tidak nyata pada semua umur pengamatan. Hal ini diduga dosis larutan yang diberikan belum cukup untuk memenuhi kebutuhan unsur hara yang diperlukan. Sesuai dengan pendapat Wijaya (2008), apabila suatu tanaman ditempatkan pada kondisi yang mendukung dengan unsur hara dan unsur mineral yang sesuai, maka tanaman tersebut akan mengalami pertumbuhan vertikal (keatas) dan menjadi lebihtinggi.

\subsection{Lingkaran Bonggol Pelepah}

Hasil sidik ragam menunjukan bahwa pemberian Trichoderma kompos (K) dan konsentrasi Gandasil D (G) serta interaksinya berbeda tidak nyata terhadap lingkaran bonggol kelapa sawit umur 216 MSP. Hasil pengamatan rata-rata lingkaran bonggol pelepah dapat dilihat pada Tabel 2. 
Tabel 2. Rekapitulasi lingkaran bonggol kelapa sawit (cm) umur 2-16 MSP dengan pemberian Trichoderma kompos dan pupuk Gandasil D

\begin{tabular}{ccccccccc}
\hline & \multicolumn{7}{c}{ Lingkaran Bonggol Pelepah $(\mathrm{cm})$} & \\
\hline Perlakuan & 2 & 4 & 6 & 8 & 10 & 12 & 14 & 16 \\
& MSP & MSP & MSP & MSP & MSP & MSP & MSP & MSP \\
\hline Trichoderma & & & & & & & & \\
Kompos (K) & tn & tn & tn & tn & tn & tn & tn & tn \\
\hline k0 & 4,06 & 4,56 & 5,29 & 5,85 & 6,67 & 7,18 & 7,72 & 8,58 \\
k1 & 4,17 & 4,87 & 5,66 & 6,32 & 7,28 & 7,70 & 8,15 & 9,36 \\
k2 & 4,22 & 4,93 & 5,58 & 6,51 & 7,68 & 8,27 & 8,93 & 9,98 \\
k3 & 3,83 & 4,48 & 5,24 & 5,91 & 6,73 & 7,23 & 7,56 & 8,82 \\
\hline Gandasil D (G) & tn & tn & tn & tn & tn & tn & tn & tn \\
\hline g0 & 3,87 & 4,52 & 5,24 & 6,13 & 6,77 & 7,27 & 8,01 & 9,09 \\
g1 & 3,91 & 4,50 & 5,33 & 5,72 & 6,59 & 7,15 & 7,42 & 8,83 \\
g2 & 4,09 & 4,68 & 5,40 & 6,03 & 7,22 & 7,62 & 8,12 & 9,23 \\
g3 & 4,40 & 5,14 & 5,79 & 6,71 & 7,78 & 8,34 & 8,82 & 9,58 \\
\hline Interaksi (KxG) & tn & tn & tn & tn & tn & tn & tn & tn \\
\hline k0g0 & 3,87 & 4,23 & 5,13 & 6,00 & 6,27 & 7,07 & 7,67 & 8,67 \\
k0g1 & 3,93 & 4,33 & 5,27 & 5,53 & 6,33 & 7,10 & 7,43 & 8,50 \\
k0g2 & 4,40 & 4,83 & 5,37 & 5,90 & 7,30 & 7,50 & 8,27 & 9,17 \\
k0g3 & 4,03 & 4,83 & 5,40 & 5,97 & 6,77 & 7,03 & 7,50 & 8,00 \\
k1g0 & 4,17 & 4,83 & 5,43 & 6,23 & 7,17 & 7,20 & 8,07 & 9,17 \\
k1g1 & 3,83 & 4,93 & 6,00 & 6,43 & 7,30 & 7,53 & 7,83 & 9,83 \\
k1g2 & 3,83 & 4,13 & 4,97 & 5,17 & 6,20 & 6,53 & 6,93 & 7,77 \\
k1g3 & 4,83 & 5,57 & 6,23 & 7,43 & 8,47 & 9,53 & 9,77 & 10,67 \\
k2g0 & 3,93 & 4,83 & 5,47 & 6,50 & 7,43 & 8,27 & 8,97 & 10,00 \\
k2g1 & 4,30 & 4,80 & 5,27 & 5,87 & 6,87 & 7,27 & 8,27 & 8,93 \\
k2g2 & 4,30 & 5,17 & 5,90 & 6,93 & 8,07 & 8,87 & 9,17 & 11,00 \\
k2g3 & 4,33 & 4,93 & 5,67 & 6,73 & 8,33 & 8,67 & 9,33 & 10,00 \\
k3g0 & 3,50 & 4,17 & 4,93 & 5,77 & 6,20 & 6,53 & 7,33 & 8,53 \\
k3g1 & 3,57 & 3,93 & 4,80 & 5,03 & 6,59 & 6,70 & 6,13 & 8,07 \\
k3g2 & 3,83 & 4,57 & 5,37 & 6,13 & 7,22 & 7,57 & 8,10 & 9,00 \\
k3g3 & 4,40 & 5,23 & 5,87 & 6,70 & 7,78 & 8,13 & 8,67 & 9,67 \\
\hline & & & & & & & & \\
\hline
\end{tabular}

Pemberian Trichoderma kompos berbeda tidak nyata pada semua umur pengamatan. Hal ini diduga pemberian pupuk NPK $10 \mathrm{~g}_{\text {tanaman }^{-1}}$ bulan.1 $^{1}$ dan unsur hara tanah dalam media tanam dapat memacu pertumbuhan bibit kelapa sawit sehingga pemberian Trichoderma yang berfungsi sebagai dekomposer tidak memberikan pengaruh pada semua perlakuan. Unsur hara NPK pada tanah diperlukan dalam jumlah yang besar untuk membentuk karbohidrat pada proses fotosintesis yang digunakan saat proses pembelahan sel dalam titik tumbuh tanaman dari hasil fotosintat sehingga mempengaruhi pertumbuhan horizontal yang mengakibatkan bertambahnya lingkaran bonggol tanaman.

Pemberian konsentrasi 6 g Gandasil D $\mathrm{L}^{-1}$ air cendrung memberikan pertumbuhan lingkaran bonggol terbesar dibandingkan dengan perlakuan lainnya meskipun tidak memberikan pengaruh secara nyata. Hal ini diduga pupuk Gandasil D dapat menyumbangkan unsur hara yang optimal bagi pertumbuhan lingkaran bonggol tanaman karena berhubungan erat dengan laju fotosintesis di daun sehingga memberikan dampak 
yang baik bagi pertumbuhan lingkaran bonggol tanaman kelapa sawit.

\subsection{Jumlah Pelepah Daun}

Hasil sidik ragam menunjukan bahwa pemberian Trichoderma kompos (K) berbeda nyata umur 4 dan 12 MSP, dan konsentrasi Gandasil D (G) berbeda nyata umur 2, 4, dan 6 MSP serta interaksinya berbeda tidak nyata terhadap jumlah pelepah daun kelapa sawit umur 2-16 MSP. Hasil pengamatan rata-rata jumlah pelepah daun dapat dilihat pada Tabel 3.

Hasil sidik ragam terhadap jumlah pelepah daun umur 4 dan 12 MSP perlakuan 500 g kompos tanaman-1 memberikan jumlah pelepah daun terbanyak yaitu 7,17 dan 10,33 buah. Perlakuan $100 \mathrm{~g}$ Trichoderma sp. tanaman-1 dan 500 g kompos tanaman-1 memberikan jumlah pelepah daun paling sedikit yaitu 5,92 dan 8,58 buah. Hal ini diduga Trichoderma belum mampu menyediakan unsur hara di dalam tanah yang berfungsi sebagai dekomposer sehingga kesuburan tanah belum mampu memenuhi kebutuhan tanaman akan unsur hara untuk pertumbuhan jumlah pelepah daun.

Pemberian konsentrasi Gandasil D berbeda nyata pada umur 2 MSP, berbeda sangat nyata pada umur 4 MSP dan berbeda nyata pada umur 6 MSP. Hal ini diduga karena unsur hara makro dan mikro yang terkandung dalam Gandasil D berpengaruh terhadap pertumbuhan dan perkembangan daun yang diperlukan dalam proses fotosintesis. Menurut Lakitan (1996), unsur hara yang paling berpengaruh terhadap pertumbuhan dan perkembangan daun adalah nitrogen.

Tabel 3. Rekapitulasi jumlah pelepah daun kelapa sawit (buah) umur 2-16 MSP dengan pemberian Trichoderma kompos dan pupuk Gandasil D

\begin{tabular}{|c|c|c|c|c|c|c|c|c|}
\hline \multicolumn{9}{|c|}{ Jumlah Pelepah Daun (buah) } \\
\hline Perlakuan & 2 & 4 & 6 & 8 & 10 & 12 & 14 & 16 \\
\hline & MSP & MSP & MSP & MSP & MSP & MSP & MSP & MSP \\
\hline $\begin{array}{l}\text { Trichoderma } \\
\operatorname{Kompos}(\mathrm{K})\end{array}$ & tn & $* *$ & tn & tn & tn & $*$ & $\operatorname{tn}$ & tn \\
\hline k0 & 6,08 & $7.00 \mathrm{~b}$ & 7,25 & 8,42 & 9,00 & $10.08 \mathrm{~b}$ & 10,83 & 11,58 \\
\hline $\mathrm{k} 1$ & 6,25 & $7.08 \mathrm{~b}$ & 7,58 & 8,75 & 9,25 & $10.17 \mathrm{~b}$ & 10,67 & 11,25 \\
\hline $\mathrm{k} 2$ & 6,33 & $7.17 \mathrm{~b}$ & 7,50 & 9,00 & 9,42 & $10.33 \mathrm{~b}$ & 10,75 & 11,33 \\
\hline $\begin{array}{c}\text { k3 } \\
\text { Nilai BNT }\end{array}$ & 5,33 & $\begin{array}{c}5.92 \mathrm{a} \\
0,68\end{array}$ & 6,58 & 7,33 & 7,92 & $\begin{array}{c}8.58 \mathrm{a} \\
1,26\end{array}$ & 9,50 & 10,08 \\
\hline $\begin{array}{l}\text { Gandasil D } \\
\text { (G) }\end{array}$ & $*$ & $* *$ & $*$ & tn & tn & tn & tn & tn \\
\hline & 5.92 & 6.83 & & & & & & \\
\hline g0 & $a b$ & $a b$ & $7.00 \mathrm{a}$ & 8,33 & 8,92 & 10,08 & 10,58 & 11,50 \\
\hline g1 & $5.58 \mathrm{a}$ & $6.42 \mathrm{a}$ & $6.75 \mathrm{a}$ & 7,83 & 8,50 & 9,42 & 10,00 & 10,50 \\
\hline $\mathrm{g} 2$ & $5.83 \mathrm{a}$ & $6.42 \mathrm{a}$ & $7.08 \mathrm{a}$ & 7,92 & 8,42 & 9,33 & 10,08 & 10,67 \\
\hline g3 & $6.67 \mathrm{~b}$ & $7.50 \mathrm{~b}$ & $8.08 \mathrm{~b}$ & 9,42 & 9,75 & 10,33 & 11,08 & 11,58 \\
\hline Nilai BNT & 0,79 & 0,68 & 0,98 & & & & & \\
\hline $\begin{array}{c}\text { Interaksi } \\
(\mathrm{KxG})\end{array}$ & tn & tn & tn & tn & tn & tn & tn & tn \\
\hline
\end{tabular}




\begin{tabular}{llllllllc}
\hline k0g0 & 5,33 & 6,67 & 6,67 & 8,00 & 8,67 & 10,33 & 10,67 & 12,00 \\
k0g1 & 6,33 & 7,33 & 7,67 & 8,67 & 9,00 & 10,00 & 10,67 & 11,33 \\
k0g2 & 6,33 & 6,67 & 7,00 & 8,00 & 9,00 & 10,00 & 11,00 & 11,67 \\
k0g3 & 6,33 & 7,33 & 7,67 & 9,00 & 9,33 & 10,00 & 11,00 & 11,33 \\
k1g0 & 7,00 & 7,67 & 7,67 & 9,00 & 10,00 & 11,00 & 11,33 & 12,00 \\
k1g1 & 6,00 & 6,67 & 7,33 & 9,00 & 9,67 & 10,67 & 11,33 & 11,67 \\
k1g2 & 4,67 & 5,67 & 6,33 & 6,33 & 6,67 & 7,67 & 8,00 & 8,67 \\
k1g3 & 7,33 & 8,33 & 9,00 & 10,67 & 10,67 & 11,33 & 12,00 & 12,67 \\
k2g0 & 6,33 & 7,00 & 7,00 & 9,33 & 9,33 & 10,33 & 10,67 & 11,33 \\
k2g1 & 5,67 & 7,00 & 7,00 & 8,00 & 9,00 & 10,00 & 10,33 & 11,00 \\
k2g2 & 6,67 & 7,00 & 7,67 & 9,00 & 9,33 & 10,33 & 11,00 & 11,33 \\
k2g3 & 6,67 & 7,67 & 8,33 & 9,67 & 10,00 & 10,67 & 11,00 & 11,67 \\
k3g0 & 5,00 & 6,00 & 6,67 & 7,00 & 7,67 & 8,67 & 9,67 & 10,67 \\
k3g1 & 4,33 & 4,67 & 5,00 & 5,67 & 6,33 & 7,00 & 7,67 & 8,00 \\
k3g2 & 5,67 & 6,33 & 7,33 & 8,33 & 8,67 & 9,33 & 10,33 & 11,00 \\
k3g3 & 6,33 & 6,67 & 7,33 & 8,33 & 9,00 & 10,33 & 10,33 & 10,67 \\
\hline
\end{tabular}

Keterangan: Angka rata-rata yang diikuti dengan huruf yang sama menunjukan berbeda tidak nyata pada uji BNT $5 \%$.

\subsection{Panjang Pelepah Daun}

Hasil sidik ragam menunjukan bahwa pemberian Trichoderma kompos (K) dan konsentrasi Gandasil D (G) serta interaksinya berbeda tidak nyata terhadap panjang pelepah daun kelapa sawit umur 2-16 MSP. Hasil pengamatan rata-rata panjang pelepah daun dapat dilihat pada Tabel 4. 
Tabel 4. Rekapitulasi panjang pelepah daun kelapa sawit (cm) umur 2-16 MSP dengan pemberian Trichoderma kompos dan pupuk Gandasil D

\begin{tabular}{|c|c|c|c|c|c|c|c|c|}
\hline \multicolumn{9}{|c|}{ Panjang Pelepah Daun $(\mathrm{cm})$} \\
\hline Perlakuan & 2 & 4 & 6 & 8 & 10 & 12 & 14 & 16 \\
\hline & MSP & MSP & MSP & MSP & MSP & MSP & MSP & MSP \\
\hline \multicolumn{9}{|l|}{ Trichoderma } \\
\hline Kompos (K) & tn & $\operatorname{tn}$ & tn & tn & tn & tn & tn & tn \\
\hline $\mathrm{k} 0$ & 17,86 & 17,87 & 21,97 & 24,65 & 27,38 & 30,35 & 34,55 & 38,29 \\
\hline $\mathrm{k} 1$ & 19,19 & 19,98 & 25,98 & 27,86 & 30,61 & 33,99 & 37,35 & 41,16 \\
\hline $\mathrm{k} 2$ & 21,37 & 21,10 & 26,35 & 28,94 & 31,54 & 35,90 & 39,41 & 42,72 \\
\hline $\mathrm{k} 3$ & 22,27 & 22,29 & 25,78 & 29,65 & 31,86 & 35,56 & 39,41 & 42,31 \\
\hline Gandasil D (G) & tn & tn & tn & tn & tn & tn & tn & tn \\
\hline g0 & 18,69 & 18,47 & 22,95 & 26,38 & 28,98 & 32,99 & 37,50 & 41,58 \\
\hline $\mathrm{g} 1$ & 19,43 & 19,36 & 24,12 & 26,12 & 28,50 & 31,61 & 34,84 & 38,69 \\
\hline $\mathrm{g} 2$ & 19,70 & 20,23 & 25,08 & 28,33 & 30,86 & 34,21 & 37,48 & 39,89 \\
\hline g3 & 22,87 & 23,18 & 27,94 & 30,25 & 33,06 & 36,98 & 40,89 & 44,31 \\
\hline Interaksi (KxG) & tn & tn & tn & tn & tn & tn & tn & tn \\
\hline k0g0 & 15,41 & 15,43 & 21,59 & 23,06 & 25,81 & 28,80 & 34,53 & 39,72 \\
\hline k0g1 & 17,04 & 16,66 & 20,11 & 22,05 & 25,27 & 27,49 & 32,27 & 35,41 \\
\hline k0g2 & 17,48 & 18,46 & 22,64 & 25,85 & 28,42 & 31,37 & 34,39 & 36,75 \\
\hline k0g3 & 21,53 & 20,91 & 23,56 & 27,63 & 30,03 & 33,74 & 37,01 & 41,28 \\
\hline k1g0 & 17,29 & 18,67 & 24,01 & 26,88 & 28,92 & 33,45 & 37,03 & 40,99 \\
\hline k1g1 & 19,31 & 20,25 & 28,08 & 28,62 & 30,90 & 34,52 & 36,98 & 41,82 \\
\hline $\mathrm{k} 1 \mathrm{~g} 2$ & 17,16 & 17,60 & 23,22 & 25,44 & 27,96 & 30,44 & 33,84 & 36,62 \\
\hline k1g3 & 23,00 & 23,40 & 28,63 & 30,50 & 34,66 & 37,53 & 41,55 & 45,22 \\
\hline $\mathrm{k} 2 \mathrm{~g} 0$ & 20,42 & 19,61 & 24,49 & 28,12 & 30,55 & 34,35 & 39,64 & 43,45 \\
\hline $\mathrm{k} 2 \mathrm{~g} 1$ & 20,38 & 19,38 & 23,13 & 25,72 & 29,45 & 33,46 & 37,26 & 41,08 \\
\hline $\mathrm{k} 2 \mathrm{~g} 2$ & 21,66 & 21,23 & 28,64 & 30,93 & 32,92 & 37,35 & 40,41 & 42,40 \\
\hline $\mathrm{k} 2 \mathrm{~g} 3$ & 23,02 & 24,18 & 29,14 & 30,97 & 33,25 & 38,43 & 40,32 & 43,93 \\
\hline $\mathrm{k} 3 \mathrm{~g} 0$ & 21,66 & 20,18 & 21,72 & 27,48 & 30,63 & 35,37 & 38,79 & 42,18 \\
\hline $\mathrm{k} 3 \mathrm{~g} 1$ & 21,00 & 21,15 & 25,17 & 28,11 & 23,38 & 30,96 & 32,85 & 36,44 \\
\hline $\mathrm{k} 3 \mathrm{~g} 2$ & 22,49 & 23,63 & 25,82 & 31,12 & 34,15 & 37,67 & 41,29 & 43,78 \\
\hline k3g3 & 23,92 & 24,22 & 30,42 & 31,91 & 34,29 & 38,23 & 44,70 & 46,82 \\
\hline
\end{tabular}

Hasil sidik ragam menunjukan pemberian perlakuan $100 \mathrm{~g}$ Trichoderma sp. $\operatorname{tanaman}^{-1}$ dan $500 \mathrm{~g}$ kompos tanaman- $^{1}$ cenderung memberikan pertumbuhan panjang pelepah daun terbaik pada semua umur pengamatan di bandingkandengan perlakuan lainnya. Hal ini diduga pemberian Trichoderma kompos mampu membantu proses laju fotosintesis yang pada akhirnya dapat memacu pertumbuhan tanaman. Peran Trichoderma sp. dalam kompos dapat mempercepat proses penguraian bahan organik sehingga berfungsi menambah unsur hara tanaman terutama unsur makro seperti N, P, K. Pemberian konsentrasi Gandasil berbeda tidak nyata pada semua umur pengamatan. Hal ini disebabkan unsur hara yang berada di media tanam sudah mencukupi untuk pertumbuhan tanaman. Unsur hara $\mathrm{N}$ dan $\mathrm{Mg}$ yang terkandung dalam Gandasil D sebagai pembentuk klorofil pada daun yang dapat meningkatkan proses fotosintesis dalam menghasilkan fotosintat yang diperlukan untuk pembelahan dan pembesaran sel pada pertumbuhan panjang pelepah daun. Sesuai pendapat Cahyo dan Ariani (2017), adanya klorofil yang cukup pada daun akan meningkatkan kemampuan 
daun dalam menyerap cahaya matahari sehingga terjadi proses fotosintesis yang kemudian menghasilkan sumber energi yang diperlukan sel-sel untuk melakukan aktifitas pembelahan dan pembesaransel.

\section{KESIMPULAN}

Berdasarkan hasil penelitian tanaman kelapa sawit (Elaeis guineensis Jacq.) di pembibitan utama dengan pemberian Trichoderma kompos dan pupuk majemuk lengkap dapat diambil beberapa kesimpulan sebagai berikut : 1) Interaksi antara Trichoderma kompos dan pupuk cair Gandasil D menunjukan berbeda tidak nyata terhadap variabel tinggi tanaman, lingkaran bonggol pelepah, jumlah pelepah daun, dan panjang pelepah daun pada semua umur pengamatan. 2) Pemberian perlakuan Trichoderma kompos berbeda tidak nyata terhadap variabel tinggi tanaman, lingkaran bonggol, dan panjang pelepah daun, tetapi berbeda nyata terhadap variabel jumlah pelepah daun. Perlakuan $500 \mathrm{~g}$ kompos tanaman $^{-1}$ memberikan pertumbuhan bibit kelapa sawit terbaik di mainnursery umur 9 bulan, yaitu dengan tinggi tanaman $74,33 \mathrm{~cm}$, lingkaran bonggol $9,98 \mathrm{~cm}$ dan jumlah pelepah daun 11,33 buah.
3) Pemberian konsentrasi pupuk Gandasil D berbeda tidak nyata terhadap variabel tinggi tanaman, lingkaran bonggol, dan panjang pelepah daun, tetapi berbeda nyata terhadap variabel jumlah pelepah daun. Perlakuan konsentrasi 6 g Gandasil $\mathrm{D} \mathrm{L}^{-1}$ air memberikan pertumbuhan bibit kelapa sawit terbaik di main nursery umur 9 bulan, yaitu dengan tinggi tanaman $72,21 \mathrm{~cm}$, lingkaran bonggol 9,58 $\mathrm{cm}$ dan jumlah pelepah daun 11,58 buah.

\section{DAFTAR PUSTAKA}

Cahyo, E.N dan Ariani, Erlida. 2017. Pemupukkan Gandasil D dan Berbagai Limbah Perkebunan Kelapa Sawit TerhadapBibit Kelapa Sawit (Elaeis guineensis Jacq.) di Pembibitan Utama. Jurnal Penelitian UNRI. 4(1): 6-7

Dinas Perkebunan Provinsi Kalimantan Timur, 2018. Badan Pusat Statistik Provinsi Kalimantan Timur. Samarinda

Harman, G. E. Hwell., Viterbo., I. Chet and Loripto. 2004. Trichoderma Species Oppourtunnistic Avirulent Plant Symbiontsi. Nature Reviews 2(1): 943 
Lakitan, B. 1996. Fisiologi Tumbuhan dan Perkembangan Tanaman. PT Raja Grafindo Persada: Jakarta

Lingga, P dan Marsono. 2008. Petunjuk Penggunaan Pupuk. Penebar Swadaya: Jakarta

Sari, VI., Sudrajat dan Sugiyanto. 2015. Peran Pupuk Organik Dalam Meningkatkan Efektivitas Pupuk NPK pada Pembibitan Utama Kelapa Sawit (Elaeis guineensis Jacq.) di Pembibitan Utama. J Agron Indonesia. 43(2) : 153-159
Wijaya, K.A. 2008. Nutrisi Tanaman Sebagai Penentu Kualitas Hasil dan Resistensi Alami Tanaman. Prestasi Pustaka: Jakarta 